\title{
Distribution and Physiologic Races of Wheat Stem Rust in Tigray, Ethiopia
}

Teklay Abebe ${ }^{1 *}$, Getaneh Woldeab ${ }^{2}$ and Woubit Dawit ${ }^{3}$

${ }^{1}$ TARI, Alamata Agricultural Research Center, PO Box 56, Alamata, Ethiopia

${ }^{2}$ EIAR, Ambo Plant Protection Research Center, PO Box 37, Ambo, Ethiopia

${ }^{3}$ Ambo University, PO Box 19, Ambo, Ethiopia

\begin{abstract}
Wheat stem rust caused by Puccinia graminis f. sp. tritici is amongst the biotic catastrophic diseases because of its ability to cause complete annihilation of wheat crops during epidemic years. The highland of Ethiopia is considered as a hot spot for the development of stem rust complex. Hence, this study was conducted to investigate the distribution and intensity; to detect the virulence diversity of the pathogen in South Tigray. The findings of this paper were based on stem rust surveys to compute the intensity; race analysis by inoculating isolates on to the 20 differential hosts. During the survey, 66 wheat fields were examined in 2010, of which $33.3 \%$ were affected. The overall mean incidence and severity of the disease were 15.6 and $8.5 \%$, respectively. A total of 20 races were identified from 32 isolates, which included the most prevalent races TTSNK, RRJJC and HRJJC. Most of the the genes possessed by the differentials were ineffective against one or more of the tested isolates except $\mathrm{Sr} 24$. Sr genes 24 and Tmp were effective in 100 and $90 \%$ of the races, respectively. In contrast, SrMcN and Sr9b were ineffective to 96.9 and $93.8 \%$ of the isolates tested, respectively. Thus, use of effective Sr genes singly or incombination with other genes through gene pyramiding has paramount importance as the additive effects of several genes offer the cultivar a wider base stem rust resistance along with periodic race survey to track further virulence evolution.
\end{abstract}

Keywords: Physiologic race; Puccinia graminis f. sp. tritici; Sr genes; Wheat stem rust

\section{Introduction}

Wheat (Triticum aesvivum L.) is one of the major crops cultivated in Ethiopia. During the last 14 years, the area covered by wheat has increased from 0.77 million ha in 1997 to 1.55 million ha in 2011, and it now ranks third among the crops next to teff (Eragrostis tef) and maize (Zea mays L) [1,2]. Wheat ranks second both in terms of volume of production and productivity after maize (Zea mays $\mathrm{L}$ ) with the total volume of production of 2.85 million tones at the national level. In Tigray region, wheat is a priority cereal crop for securing food security. In the region, wheat covers over 0.1 million ha with total production of about 1.93 million quintals per year. Of which $46.3 \%$ of the area and $44.7 \%$ of the production comes from the South part of the region [2].

However, productivity of wheat in Ethiopia in general and Tigray in particular is very low. The low productivity is attributed to a number of factors including biotic (diseases, insects, and weeds), abiotic, and low adoption of new agricultural technologies. Among these factors, wheat stem rust, also known as black rust, caused by the fungus Puccinia graminis $\mathrm{f}$. sp. tritici has been the most devastating disease of all wheat rusts in Ethiopia causing up to complete annihilation of wheat crops over wide areas during epidemic years. The high virulence diversity and evolution rate of the pathogen makes a considerable proportion wheat germplasm at risk [3]. According to [4], the highland of Ethiopia is considered as a hot spot for the development of stem rust diversity. In addition, the wheat based mono-cropping system and the continuous release and extensive cultivation of CIMMYT originated bread wheat genotypes with similar genetic background (commonality in parentage) which could serve as the breeding ground/reemergence for new physiological races of stem rust that can attack previously resistant cultivars. Furthermore, studies that were carried out in Ethiopia showed that most previously identified races were virulent on most of varieties grown in the country $[3,5]$ and are among the most virulent in the world [6]. Wheat stem rust can be effectively controlled by growing resistant varieties. However, the evelopment of resistant varieties requires a knowledge of the pathogen population, virulence diversity and race distribution in particular region and time, and which resistance genes are effective against these races. In addition, virulence surveys are important for studying the evolution of new races and forecasting the virulence shifts in a population. Hence, this study was initiated to determine the distribution and virulence diversity of wheat stem rust.

\section{Materials and Methods}

\section{Survey of wheat stem rust in wheat growing areas of south Tigray}

Field stem rust survey was conducted on 66 farmers' fields in 2010 main growing season, in the major wheat growing areas of South Tigray, Ethiopia. Private farms in five districts (Ofla, Enda-Mekoni, Emba-Alage, Raya-Alamata and Raya-Azebo) were included in the assessment. The survey was conducted at $5-10 \mathrm{~km}$ intervals on wheat fields along the main and accessible roadsides. Stem rust incidence and severity were recorded at five random spots along the two diagonals of the field using quadrant and used to calculate average values. The incidence of wheat stem rust was calculated by using the number of infected plants and expressed as a percentage of the total number of plants assessed. Similarly, the severity of the disease was examined visually on the whole plants within the quadrants and recorded as the percentage of plant part (tissue) affected (percentage of rust infection of the plant), and plant response (type of infection) using modified Cobb's

*Corresponding author: Teklay Abebe, TARI, Alamata Agricultural Research Center, PO Box 56, Alamata, Ethiopia, Tel: +251347740546; Fax: +251347740333; E-mail: teklayabebe6@gmail.com

Received September 14, 2012; Accepted October 15, 2012; Published October 20, 2012

Citation: Abebe T, Woldeab G, Dawit W (2012) Distribution and Physiologic Races of Wheat Stem Rust in Tigray, Ethiopia. J Plant Pathol Microb 3:142. doi:10.4172/2157-7471.1000142

Copyright: (C) 2012 Abebe T, et al. This is an open-access article distributed under the terms of the Creative Commons Attribution License, which permits unrestricted use, distribution, and reproduction in any medium, provided the original author and source are credited. 
scoring scale of rust disease under field conditions [7]. The prevalence of the disease was computed using the number of fields affected divided by total number of fields assessed and expressed in percentage. The mean temperature of Ofla, Enda-Mekoni, Emba-Alage, Raya-Alamata and Raya-Azebo distrcts were $22^{\circ} \mathrm{C}, 25^{\circ} \mathrm{C}, 24^{\circ} \mathrm{C}, 28^{\circ} \mathrm{C}$ and $29^{\circ} \mathrm{C}$ as well as the mean rainfall was $825 \mathrm{~mm}, 750 \mathrm{~mm}, 700 \mathrm{~mm}, 533 \mathrm{~mm}$ and 500 $\mathrm{mm}$, respectively.

\section{Identification of physiological races of $P$. graminis $\mathrm{f}$. sp. tritici}

Collection of wheat stem rust samples: Samples of infected stems (one sample per field) were collected at 5-10 km interval from wheat fields and trial plots in South Tigray, Ethiopia. Stems and/or leaf sheath of wheat plants infected with stem rust were cut into small pieces of $5-10 \mathrm{~cm}$ in length using scissors and placed in paper bags after the leaf sheath was separated from the stem in order to keep stem and/or leaf sheath dry. This technique helps the samples easily air dry (reduce moisture) so as the spores cannot germinate before processing in the greenhouse. The samples collected in the paper bags were labeled and transported to Ambo Plant Protection Research Center's (APPRC) Laboratory for analysis.

Isolation and multiplication of single-pustules: Seedlings of the universally rust susceptible variety "Morocco" which does not carry known stem rust resistance genes were raised in suitable $8 \mathrm{~cm}$ diameter pots. Leaves of seven-day-old seedlings or seedlings with fully expanded primary leaves and second leaves beginning to grow, were rubbed gently with clean moistened fingers. By this way, the waxy layer that hinders the penetration of the spores were removed from the surface of the leaves. Greenhouse inoculations were done using the methods and procedures developed by Stakman and his colleagues [8]. Spores from the stem rust infected sample were scraped off with scalpels on to a watch glass and suspended in distilled water to make rust spore suspension, which was rubbed on the seedlings of Morocco. The plants were then moistened with fine droplets of distilled water produced with an atomizer and placed in an incubation chamber for 18 hours dark at $18-22^{\circ} \mathrm{C}$ followed by exposure to light for 3-4 hours to provide condition for infection and seedlings were allowed to dry thier dew for about 1-2 hours. Then, the seedlings were transferred from the dew chamber to glass compartments in the greenhouse where conditions was regulated at 12 hours photoperiod, at temperature of $18-25^{\circ} \mathrm{C}$ and relative humidity $(\mathrm{RH})$ of $60-70 \%$. The remaining rust spore samples were kept in the refrigerator at $4^{\circ} \mathrm{C}$ and were used to substitute for samples which failed to produce infection on the universally susceptible variety in greenhouse. After seven to ten days of inoculation (when the flecks/symptoms was clearly visible) leaves containing a single fleck that produce single pustule was selected from the base of the leaves and the remaining seedlings within the pots were removed using scissors. Only 2-3 leaves with single pustule were separately covered with cellophane bags $(145 \times 235 \mathrm{~mm})$ and tied up at the base with a rubber band to avoid cross contamination [9].

After two weeks of inoculation (when the pustule was well developed), spores from each pustule were collected using power operated vacuum aspirator and stored separately in gelatine capsules. A suspension, prepared by mixing urediospores with lightweight mineral oil (Soltrol 130), was inoculated on seven-day-old seedlings of the susceptible variety 'Morocco' for multiplication purpose for each of the single pustules on separate pots. Immediately after inoculation, the seedlings were placed in a humid chamber in dark condition at $18-22^{\circ} \mathrm{C}$ for 18 hours and light for 3-4 hours, after which they were transferred to a greenhouse where the temperature varied between 18 and $25^{\circ} \mathrm{C}$ and $\mathrm{RH}$ of $60-70 \%$ following the procedures mentioned earlier. About 14-15 days after inoculation, the spores of each single pustule were collected in separate test tubes and stored at $4^{\circ} \mathrm{C}$ until they were inoculated on the standard differential sets. This spore multiplication procedure was repeated until sufficient spores were produced to inoculate the set of stem rust differential hosts. In this way, total of 32 single pustule isolates were developed from 16 of wheat stem rust samples.

Inoculation of wheat stem rust differential hosts: Five seeds of the twenty wheat stem rust differentials with known resistance genes (Table 1) and one susceptible variety Morocco were grown in $3 \mathrm{~cm}$ diameter pots separately in greenhouse. The susceptible variety Morocco (without Sr gene) was used to ascertain the viability of spores inoculated to the differential hosts. The single pustule derived spores (approximately 3-5 $\mathrm{mg}$ of spores per $\mathrm{ml}$ of liquid suspension) was suspended in distilled water and sprayed/inoculated onto seven-dayold seedlings using atomizers and/or an air pump. After inoculation, plants were moistened with fine droplets of distilled water produced with an atomizer and placed in an incubation chamber for 18 hours dark period at $18-22^{\circ} \mathrm{C}$ and $3-4$ hours of light and seedlings were allowed to remove thier dew for about 1-2 hours. Upon removal from the dew chamber, plants were placed in separate glass compartments in a greenhouse to avoid contamination and produce infection. Greenhouse temperature was maintained between $18^{\circ} \mathrm{C}$ and $25^{\circ} \mathrm{C}$ Natural daylight was supplemented for additional 4 hours/day with 120 $\mu$ E.M $\mathrm{M}^{-2} \mathrm{~S}^{-1}$ photo synthetically active radiations emitted by cool white fluorescent tubes arranged directly above plants.

Phenotyping differential sets and designation of races: Determination of races were based on the reaction of the inoculated differntial hosts. Stem rust infection types (ITs) were scored 14 days after inoculation using the 0-4 scale [8]. Infection types were grouped into two, where, low (resistance $)=(0,0$; (fleck), $1,1+, 2$ and $2+)$ and high (susceptible) $=(3-, 3+$ and 4$)$. Race designation was done by grouping the differential hosts into five subsets in the following order: (i) Sr5, Sr21, Sr9e, Sr7b; (ii) Sr11, Sr6, Sr8a, Sr9g; (iii) Sr36, Sr9b, Sr30, Sr17; (iv) Sr9a, Sr9d, Sr10, SrTmp; and (v) Sr24, Sr31, Sr38, and SrMcN (Table 2).

\begin{tabular}{|l|l|l|}
\hline Differential hosts & Sr genes & Origin/Pedigree \\
\hline LcSr24Ag & 24 & Little Club/Agent $(\mathrm{Cl} 13523)$ \\
\hline W2691SrTt-1 & 36 & Cl12632 T. timopheevii \\
\hline ISr7b-Ra & $7 \mathrm{~b}$ & Hope/Chinese Spring \\
\hline ISr8a-Ra & $8 \mathrm{a}$ & Rieti/Wilhelmina//Akagomughi \\
\hline CnSSrTmp & $\mathrm{Tmp}$ & Triumph 64(CI 13679)/ Chinese Spring \\
\hline Sr31(Benno)/6*LMPG & 31 & Kavkaz \\
\hline CnS-T-.mono-deriv & 21 & Einkorn Cl 2433 \\
\hline Trident & 38 & Spear*4/VM (PI519303) \\
\hline ISr9a-Ra & $9 \mathrm{a}$ & Red Egyptian/Chinese Spring \\
\hline ISr9d-Ra & $9 \mathrm{~d}$ & Hope/Chinese Spring \\
\hline Combination VII & 17 & Esp 518/9 \\
\hline ISr5-Ra & 5 & Thatcher/Chinese Spring \\
\hline ISr6-Ra & 6 & Red Egyptian/Chinese Spring \\
\hline W2691Sr9b & $9 \mathrm{~b}$ & Kenya 117A \\
\hline Vernsteine & $9 \mathrm{e}$ & Little Club//3*Gabo/2* \\
\hline W2691Sr10 & 10 & Marquis*4/Egypt NA95/2/2*W2691 \\
\hline BtSr30Wst & 30 & Festival/Uruguay C10837 \\
\hline CnsSr9g & $9 \mathrm{~g}$ & Selection from Kubanka(Cl1516) \\
\hline ISr11-Ra & 11 & Kenya C6402/Pusa4/Dundee \\
\hline McNair 701 & McN & Cl 15288 \\
\hline
\end{tabular}

Source: Ambo Plant Protection Research Center, 2009/10

Table 1: List of twenty wheat stem rust differential hosts with their corresponding $\mathrm{Sr}$ genes \& origin/pedigree. 


\begin{tabular}{|l|l|l|l|l|l|}
\hline \multirow{3}{*}{ Pgt-code } & \multicolumn{5}{|c|}{ Infection phenotype of pathogen and wheat Pgt gene } \\
\cline { 2 - 6 } & Set 1 & 5 & 21 & $9 \mathrm{e}$ & $7 \mathrm{~b}$ \\
\cline { 2 - 6 } & Set 2 & 11 & 6 & $8 \mathrm{a}$ & $9 \mathrm{~g}$ \\
\cline { 2 - 6 } & Set 3 & 36 & $9 \mathrm{~b}$ & 30 & 17 \\
\cline { 2 - 6 } & Set 4 & $9 \mathrm{a}$ & $9 \mathrm{~d}$ & 10 & Tmp \\
\cline { 2 - 6 } & Set 5 & 24 & 31 & 38 & McN \\
\hline B & & Low & Low & Low & Low \\
\hline C & & Low & Low & Low & High \\
\hline D & & Low & Low & High & Low \\
\hline F & & Low & Low & High & High \\
\hline G & & Low & High & Low & Low \\
\hline H & & Low & High & Low & High \\
\hline J & Low & High & High & Low \\
\hline K & & Low & High & High & High \\
\hline L & & High & Low & Low & Low \\
\hline M & & High & Low & Low & High \\
\hline N & & High & Low & High & Low \\
\hline P & & High & Low & High & High \\
\hline Q & & High & High & Low & Low \\
\hline R & & High & High & Low & High \\
\hline S & & High & High & High & Low \\
\hline T & & High & High & High & High \\
\hline & & & & & \\
\hline
\end{tabular}

L=low ITs (0 to $2+$ ), $\mathrm{H}=$ high ITs (3- to 4 )

Table 2: Nomenclature of $P$. graminis f. sp. tritici based on 20 differential wheat hosts.

\begin{tabular}{|l|l|l|l|l|l|l|l|}
\hline District & $\begin{array}{l}\text { Altitude } \\
\text { range (masl) }\end{array}$ & $\begin{array}{l}\text { No. of fields } \\
\text { inspected }\end{array}$ & $\begin{array}{l}\text { Prevalence } \\
(\%)\end{array}$ & $\begin{array}{l}\text { Incidence } \\
(\%)\end{array}$ & \multicolumn{3}{l|}{$\begin{array}{l}\text { Severity } \\
(\%)\end{array}$} \\
\hline Raya-Azebo & $1551-1772$ & 16 & 81.3 & $0-100$ & 42.3 & $0-80$ & 26.7 \\
\hline Alamata & $1494-2512$ & 9 & 55.6 & $0-100$ & 33.3 & $0-50$ & 12.3 \\
\hline Ofla & $1798-2727$ & 16 & 12.5 & $0-10$ & 0.6 & $0-5$ & 0.5 \\
\hline EndaMekoni & $2288-2977$ & 14 & 7.1 & $0-5$ & 0.4 & $0-5$ & 0.4 \\
\hline Emba-Alaje & $1784-2764$ & 11 & 9.1 & $0-15$ & 1.4 & $0-10$ & 0.9 \\
\hline Total/mean & $1494-2977$ & 66 & 33.3 & $0-100$ & 15.6 & $0-80$ & 8.5 \\
\hline
\end{tabular}

Table 3: Prevalence and intensity of wheat stem rust in five districts of South Tigray in 2010 .

Each isolate was assigned a five letter race code based on its reaction on the differential hosts $[10,11]$. For instance, low IT on the four hosts in a set is assigned with the letter ' $\mathrm{B}$ ', while high IT on the four hosts is assigned with a letter ' $T$ '. Hence, if an isolate produces low infection type (resistant reaction) on the 20 differential hosts, the race will be assignated with a five letter race code 'BBBBB'. In the same way, an isolate which produces a high IT (susceptible reaction) on the 20 wheat differential hosts have a race code 'TTTTT'. If an isolate produces a low IT on Sr36, SrTmp, and Sr24, but a high infection type on the remaining 17 differential hosts, the race will be designated as TTKSK (Ug99) (Table 2).

\section{Results}

\section{Distribution and intensity of wheat stem rust in south Tigray, Ethiopia}

In the main crop-growing season of 2010, 66 wheat fields planted with improved and local cultivars were assessed for the intensity of the disease. Stem rust was observed in all surveyed districts at variable levels. The result of the survey revealed that the intensity of the disease vary from slight to complete infection of wheat fields depending on the crop type (bread vs durum wheat), variety and agro-ecological divergence. During the survey, stem rust was observed on $22(33.3 \%)$ of the 66 wheat fields inspected. The number of fields assessed in RayaAzebo, Alamata, Ofla, Enda-Mekoni and Emba-Alaje districts were 16, $9,16,14$, and 11 of which $13,5,2,1$, and 1 were affected with stem rust, following the same order. The highest mean (42.3\%) incidence of stem rust was recorded in Raya-Azebo district, while lowest the score $(0.4 \%)$ was noted in Enda-Mekoni. The second highest mean stem rust incidence (33.3\%) was registered in Alamata district; whereas the incidence of the disease for the rest of the three disricts was below one percent. The overall mean incidence for the five disricts of the South Tigray reached $15.6 \%$. Likewise, the disease severity showed similar trend as the incidence. The highest severity was recorded in RayaAzebo district with range and mean severity values of $0-80 \%$ and $26.7 \%$, respectively (Table 3 ). This was followed by Alamata district, with a range of $0-50 \%$ and mean severity of $12.3 \%$. The highest severity $(80 \%)$ was recorded where the highest incidence $(100 \%)$ was noted at Raya-Azebo district. The severities for the rest of the three districts (Enda-Mekoni, Ofla and Emba-Alaje) were with range of 0-15\% and mean values of below one percent (Table 3 ).

Of the fields inspected, $37.9 \%$ of the fields surveyed were found at altitudes below 1800 masl, while $22.7 \%$ was found between 1800 2300 masl and the remaining $39.4 \%$ was located above 2300 masl. The highest prevalence $(68 \%)$ of stem rust was recorded at lower elevation (1494-1800 masl) followed by 66.1\% prevalence at 1801-2300 masl and none in any of the higher altitudes ( $>2300$ masl). In a similar way, the incidence of the disease varied from 0 to $37.7 \%$ at higher ( $>2300$ masl) and lower $(<1800$ masl) and severity from 0 to $21 \%$, in that order.

\section{Infection type of commercial wheat varieites to stem rust}

The survey also revealed that the susceptibility of wheat cultivars mainly cultivated in the region. The most dominant varieties grown by the farmers in Tigray were Kubsa (HAR-1685), Dashen (HAR-408), Shinna (HAR-1868) local, Hawi (HAR-2501) and few others recently introduced improved bread wheat varieties (Table 4).

\begin{tabular}{|c|c|c|c|}
\hline $\begin{array}{c}\text { Culti- } \\
\text { var }\end{array}$ & $\begin{array}{c}\text { Wheat } \\
\text { type }\end{array}$ & Code & Pedigree \\
\hline Dashen & Bread & HAR 408 & VEE 17/KVZ/BUHO"S"//KAL/BB \\
\hline Tura & Bread & HAR-1775 & ARO YR SEL. 60/89 \\
\hline Hawi & Bread & HAR-2501 & CHIL/PRL \\
\hline Shina & Bread & HAR-1868 & $\begin{array}{c}\text { GOV9/AZ//MUS"S"/3/R37GHL/21//KAL/BB/4/ } \\
\text { ANI"S" }\end{array}$ \\
\hline KBG-01 & Bread & FH-1-7-A & 300 /SM+501M/HAR 1709 \\
\hline Kubsa & Bread & HAR1685 & NDG9144//KAL/BB/3/YACO"S"/4VEE\#5"S" \\
\hline Local & Durum & - & - \\
\hline
\end{tabular}

Source: AARC and APPRC, 2010

Table 4: List of wheat cultivars used for evaluation of stem rust races at seedling stage.

\begin{tabular}{|c|c|c|c|c|c|c|c|}
\hline \multirow{3}{*}{\begin{tabular}{|l|} 
Variety \\
$\begin{array}{l}\text { Dashen } \\
\text { Shina }\end{array}$ \\
\end{tabular}} & \multirow{3}{*}{\begin{tabular}{|l|}
$\begin{array}{l}\text { Altitude } \\
\text { range }(\mathrm{m})\end{array}$ \\
$1494-2977$ \\
$1613-2765$
\end{tabular}} & \multirow{3}{*}{$\begin{array}{l}\text { Fields } \\
\text { inspected }\end{array}$} & \multirow{3}{*}{\begin{tabular}{|l|} 
Prevalence \\
(\%) \\
46.7 \\
10 \\
\end{tabular}} & \multicolumn{2}{|c|}{ Incidence (\%) } & \multirow{2}{*}{\multicolumn{2}{|c|}{$\begin{array}{l}\text { Severity (\%) } \\
\text { Range mean }\end{array}$}} \\
\hline & & & & \multirow{2}{*}{\begin{tabular}{|l|} 
Range \\
$0-100$ \\
$0-100$ \\
\end{tabular}} & \multirow{2}{*}{\begin{tabular}{|l|} 
mean \\
25.4 \\
10 \\
\end{tabular}} & & \\
\hline & & & & & & $\begin{array}{l}0-80 \\
0-80\end{array}$ & $\begin{array}{l}14.5 \mathrm{~S} \\
8 \mathrm{MS}\end{array}$ \\
\hline $\begin{array}{l}\text { Tura } \\
\text { KBG-01 }\end{array}$ & $\begin{array}{l}2350-2490 \\
2492\end{array}$ & $\begin{array}{l}3 \\
1\end{array}$ & $\begin{array}{l}0 \\
0\end{array}$ & $\begin{array}{l}0 \\
0\end{array}$ & $\begin{array}{l}0 \\
0\end{array}$ & $\begin{array}{l}0 \\
0\end{array}$ & $\begin{array}{l}0 \\
0\end{array}$ \\
\hline Local $^{*}$ & $1722-2724$ & 11 & 18.2 & $0-10$ & 3.5 & $0-30$ & 1.3MR \\
\hline Hawi & $1654-2456$ & 5 & 20 & $0-5$ & 0.6 & $0-1$ & $0.2 \mathrm{tR}$ \\
\hline Kubsa & $1613-2490$ & 21 & 52.4 & $0-100$ & 30.2 & $0-90$ & $25 S$ \\
\hline
\end{tabular}

*Durum wheat, S-susceptible, MS-moderately susceptible, tR-trace, MRmoderately resistant

Table 5: Reaction/infection types of wheat cultivars to stem rust in South Tigray in 2010. 
During the survey, varieties such as Shinna, Kubsa, Hawi and Dashen were highly susceptible to stem rust. The stem rust incidence and severity in these varieties varied between $0-100 \%$ and $0-90 \%$, respectively (Table 5). Varieites Tura and KBG-01 were found free of infection during survey mainly due to growing of at higher elevation.

\section{Physiological races and virulence diversity wheat stem rust in south Tigray}

Determination of the physiologic race of $P$. graminis $\mathrm{f}$. sp. tritici resulted in identification of 20 races, which have a wider range of virulence spectrum on the wheat differential hosts.

Virulence and physiologic race composition of $P$. graminis $\mathrm{f}$. sp. tritici: From 16 field samples from the Sothern zone of Tigray, 32 single pustule-derived isolates (two isolates per sample) were developed. Hence, 32 isolates were used for race analysis. Using the international system of nomenclature for $P$. graminis $\mathrm{f}$. sp. tritici, 20 races were identified based on their reaction on 20 differential hosts. This indicated a high level of variation. The highest level of race variation was detected from Raya-Azebo district accounting for $65 \%$ of the races identified. Out of the total 20 races, 13 were identified from 22 isolates in this particular district. The remaining 35\% of the races were detected from Raya-Alamata, Ofla and Enda-Mekoni districts (Table 6).

The frequency of each race was calculated as a percentage from the total number of isolates analyzed. Of the 20 races, the most frequent and predominant races identified were TTSNK, RRJJC, and HRJJC with a frequency of $9.4 \%$ each. The second most frequent and dominant races were BHJBC, GMHSC, HHSTF, RRTTF, SPSSF, and SKGNH, with a frequency of $6.3 \%$ each. Conversely, the remaining 11 races were detected only once each with a frequency of $3.1 \%$ (Table 7 ).

The 20 races identified from wheat grown areas in South Tigray had wide virulence spectra (Table 5). The broadest virulence spectra were recorded for races TTKSK and TTSSK making 17 stem rust resistance genes ineffective. TTKSK (Ug99) was virulent to $17 \mathrm{Sr}$ genes except Sr36, Sr24, and SrTmp. Similarly, race TTSSK was virulent to all the resistance genes except Sr17, SrTmp, and Sr24. In the same way, TTSNK and RRTTF were equally virulent to $80 \%$ of the stem rust resistance genes. On the other hand, eight races or $40 \%$ of the races identified were virulent on less than $50 \%$ of the $20 \mathrm{Sr}$ genes included in this study. Race BBBBC was the least virulent, producing susceptible reaction on only monogenic gene, SrMcN. Races such as BBBLC, CCGBC, BHJBC, and DBHQC were also the least virulent, producing susceptible reactions on two, four, five, and six wheat differential hosts, respectively (Table 7 ).

Virulence frequency of $\boldsymbol{P}$. graminis $\mathrm{f}$. sp. tritici isolates to $\mathrm{Sr}$ resistant genes: About $55 \%$ of the Sr genes were ineffective to more than $60 \%$ of the isolates. The differential host carrying the resistance gene McNair 701 ( $\mathrm{SrMcN}$ ) was ineffective to $96.9 \%$ of the isolates tested. Similarly, six differential hosts carrying resistance genes Sr9d, Sr21, Sr6, Sr10, Sr9g, and Sr9b were ineffective, with virulence

\begin{tabular}{|c|c|c|}
\hline District & Race & Isolate \\
\hline Raya-Alamata & BBBBC, HHSTF, and JRGSC & 4 \\
\hline Raya-Azebo & $\begin{array}{c}\text { BBBLC, BHJBC, CCGBC, GMHJC, HRJJC, JTGDB, } \\
\text { RRTTF, SKQNH, SPSSF, TCQJH, TTKSK, TTSNK, } \\
\text { and TTSSK }\end{array}$ & 22 \\
\hline Ofla & DBHQC and DBHSC & 2 \\
\hline Enda-Mekoni & GKJSF and RRJJC & 4 \\
\hline
\end{tabular}

Table 6: Prevalence of races of $P$. graminis f. sp. tritici across district in south Tigray.

\begin{tabular}{|c|c|c|c|}
\hline Race & Virulence spectrum (ineffective Sr genes) & $\begin{array}{l}\text { No. of } \\
\text { isolates }\end{array}$ & $\begin{array}{c}\text { Frequency } \\
(\%)\end{array}$ \\
\hline BBBBC & $\mathrm{McN}$ & 1 & 3.1 \\
\hline BBBLC & $9 a, \mathrm{McN}$ & 1 & 3.1 \\
\hline BHJBC & $6,9 \mathrm{~g}, 9 \mathrm{~b}, 30, \mathrm{McN}$ & 2 & 6.3 \\
\hline CCGBC & $7 b, 9 g, 9 b, M c N$ & 1 & 3.1 \\
\hline DBHQC & $9 e, 9 b, 17,9 a, 9 d, M c N$ & 1 & 3.1 \\
\hline DBHSC & $9 \mathrm{e}, 9 \mathrm{~b}, 17,9 \mathrm{a}, 10,9 \mathrm{~d}, \mathrm{McN}$ & 1 & 3.1 \\
\hline GKJSF & $21,6,8 a, 9 g, 9 b, 30,9 a, 9 d, 10,38, M c N$ & 1 & 3.1 \\
\hline GMHJC & $21,11,6,9 \mathrm{~g}, 9 \mathrm{~b}, 17,9 \mathrm{~d}, 10, \mathrm{McN}$ & 2 & 6.3 \\
\hline HHSTF & $\begin{array}{l}21,7 \mathrm{~b}, 6,9 \mathrm{~g}, 36,9 \mathrm{~b}, 30,9 \mathrm{a}, 9 \mathrm{~d}, 10, \mathrm{Tmp}, 38 \\
\operatorname{McN}\end{array}$ & 2 & 6.3 \\
\hline HRJJC & $21,7 b, 11,6,9 g, 9 b, 30,9 d, 10, \mathrm{McN}$ & 3 & 9.4 \\
\hline JRGSC & $21,9 e, 11,6,9 g, 9 b, 9 a, 9 d, 10, \mathrm{McN}$ & 1 & 3.1 \\
\hline JTGDB & $21,9 \mathrm{e}, 11,6,8 \mathrm{a}, 9 \mathrm{~g}, 9 \mathrm{~b}, 10$ & 1 & 3.1 \\
\hline RRJJC & $5,21,7 \mathrm{~b}, 11,6,9 \mathrm{~g}, 9 \mathrm{~b}, 30,9 \mathrm{~d}, 10, \mathrm{McN}$ & 3 & 9.4 \\
\hline RRTTF & $\begin{array}{l}\text { 5, 21, 7b, 11, 6, 9g, 36, 9b, 30, 17, 9a, 9d, } 10 \\
\text { Tmp, } 38, \text { McN }\end{array}$ & 2 & 6.3 \\
\hline SKQNH & $5,21,9 e, 6,8 a, 9 g, 36,9 b, 9 a, 10,31, \mathrm{McN}$ & 2 & 6.3 \\
\hline SPSSF & $\begin{array}{l}\text { 5, 21, 9e, 11, 8a, 9g, 36, 9b, 30, 9a, 9d, } 10 \text {, } \\
38, \mathrm{McN}\end{array}$ & 2 & 6.3 \\
\hline TCQJH & $5,21,9 e, 7 b, 9 g, 36,9 b, 9 d, 10,31, M c N$ & 1 & 3.1 \\
\hline TTKSK & $\begin{array}{l}5,21,9 \mathrm{e}, 7 \mathrm{~b}, 11,6,8 \mathrm{a}, 9 \mathrm{~g}, 9 \mathrm{~b}, 30,17,9 \mathrm{a}, 9 \mathrm{~d} \\
10,31,38, \mathrm{McN}\end{array}$ & 1 & 3.1 \\
\hline TTSNK & $\begin{array}{l}5,21,9 e, 7 b, 11,6,8 a, 9 g, 9 b, 36,30,9 a, 10 \\
31,38, M c N\end{array}$ & 3 & 9.4 \\
\hline TTSSK & $\begin{array}{l}5,21,9 \mathrm{e}, 7 \mathrm{~b}, 11,6,8 \mathrm{a}, 9 \mathrm{~g}, 9 \mathrm{~b}, 36,30,9 \mathrm{a}, 9 \mathrm{~d} \\
10,31,38, \mathrm{McN}\end{array}$ & 1 & 3.1 \\
\hline Total & & 32 & 100 \\
\hline
\end{tabular}

Table 7: Virulence spectrum and frequency of races of $P$. graminis f. sp. tritici collected from southern zone of Tigray in 2010.

\begin{tabular}{|l|l|l|l|}
\hline Sr gene & Virulence frequency (\%) & Sr gene & Virulence frequency (\%) \\
\hline 5 & 46.9 & 30 & 62.5 \\
\hline 21 & 78.1 & 17 & 21.9 \\
\hline $9 \mathrm{e}$ & 43.8 & $9 \mathrm{a}$ & 56.25 \\
\hline $7 \mathrm{~b}$ & 53.1 & $9 \mathrm{~d}$ & 75.0 \\
\hline 11 & 59.4 & 10 & 81.5 \\
\hline 6 & 75.0 & $\mathrm{Tmp}$ & 12.5 \\
\hline $8 \mathrm{a}$ & 31.3 & 24 & 0.0 \\
\hline $9 \mathrm{~g}$ & 87.5 & 31 & 25 \\
\hline 36 & 40.6 & 38 & 37.5 \\
\hline $9 \mathrm{~b}$ & 93.8 & $\mathrm{McN}$ & 96.9 \\
\hline
\end{tabular}

Table 8: Virulence frequency of $P$. graminis f. sp. tritici isolates (32) on $20 \mathrm{Sr}$ genes.

frequencies of $65.6,78.1,75,81.2,87.5$, and $93.8 \%$ to the isolates tested, respectively (Table 8 ).

On the other hand, the stem rust resistance gene Sr24 was effective to all stem rust isolates collected from Southern Tigray region. Five resistance genes, SrTmp, Sr17, Sr31, Sr36, and Sr38 were found to be effective against most of the stem rust races detected. Of these $\mathrm{Sr}$ genes, the differential hosts carrying SrTmp, Sr31, and Sr17 were resistant to $87.5,75.0$, and $78.1 \%$ of the isolates tested, respectively. Correspondingly, gene Sr38 was effective against $62.5 \%$ of the isolates analyzed followed by Sr36 which was effective against 59.4\%.

\section{Discussion}

Stem rust is a major disease of wheat in Ethiopia in general and Tigray region in particular and they can cause significant yield losses and quality in years with suitable conditions. The intensity of the disease changes from year to year and from place to place depending on 
type of variety grown and climatic conditions [12]. The disease is more important at Raya-Azebo and Raya-Alamata than the three districts (Ofla, Enda-Mekoni and Emba-Alaje). The majority of the wheat fields assessed in Raya-Azebo and Alamata have lower elevation ( $<1800$ masl) as compared to the elevation in the other districts. So, this elevation range had warmer climate which is suitable for the development of stem rust. Earlier studies also revealed that stem rust is prevalent at lower altitudes $[13,14]$. This field assessment showed the susceptibility of commercial bread wheat varieties when they were compared with durum wheat (local) cultivars which were grown by small scale farmers. This finding was also in agreement with the previous reports, which stated that the Ethiopian cultivated tetraploid (durum) wheat accessions are resistant or moderately resistant to stem rust, and the landraces are found to be a potential source of resistance to stem rust $[15,16]$. Similarly, most commercial bread wheat varieties have shown susceptibility to stem rust, and most of the varieties released since the inception of wheat breeding in 1950s up to date are abandoned due to the disease [12,17].

Wheat stem rust declined for several decades because of the widespread use of the 1BL.1RS translocation carrying Sr31, effective against all known $P$. graminis $\mathrm{f}$. sp. tritici races. However, the most devastating stem rust race TTKSK (commonly known as Ug99) virulence on gene Sr31 was first detected in Uganda in 1999 [17,18], and had spread to most of the wheat growing areas of Kenya in 2002 and Ethiopia in 2003. In 2005, Ethiopian reports confirmed its presence in six dispersed locations [19], and was spread to most wheat growing regions of the country and is becoming the main threat of wheat production [3]. The present study also detected the race at additional one location, indicating the race is getting spreads in the region. Furthermore, the new Ug99 variant TTSSK, which is identified in this study, was also detected in Kenya in 2006 and 2007 with virulence to gene Sr36 indicates that Ug99 is evolving [19]. In general, the virulence spectrum of the pathogen in this study confirmed the presence of wider range of virulence in the study area and is inline with previous studies conducted in Ethiopia [3,5]. A comparison of the races identified in the present study with these earlier reports revealed differences. This could be due to variation over location and time, as the prevalence of races in a specific season and region depends on the type of wheat cultivars grown and to some extent on the predominant environmental conditions, especially temperature [14].

It was evident that the majority of the resistance genes were ineffective against most of the isolates. Resistance genes SrMcN, Sr9d, Sr21, Sr6, Sr10, Sr9g, and Sr9b were ineffective, accounting for more than $65 \%$ of the isolates tested. These Sr genes were ineffective for more than $85 \%$ of the isolates collected during 2006-2007 cropping season from Shewa, Arsi, Bale, and northwest regions of Ethiopia [3]. Earlier studies indicated that virulence to Sr6, Sr8b, Sr9a, Sr9d, and Sr11 is common worldwide [14]. In contrast, Sr24 and SrTmp were effective against all and most of the isolates tested, respectively. This confirms the report [14] which states that these genes are amongst the effective genes, which have an adequate and some immediate values to almost all races in the world, except occasional high infection types in some countries including Ethiopia. For instance, virulence to Sr24 was reported in Kenya in 2006. A variant of Ug99 that added virulence on stem rust gene Sr24 (Ug99+Sr24 virulence, called TTKST) has further increased the vulnerability of wheat to stem rust worldwide [11]. Furthermore, the most important gene Sr24 was also defeated by another race PTKST, which is detected in Ethiopia in 2007 and Kenya and South Africa in 2009. This represents the first confirmed occurrence of Ug99 variant with virulence to Sr24 in Ethiopia [20].

\section{Acknowledgements}

I am greatly indebted to my advisor Dr. Getaneh Woldeab and co-advisor Dr. Woubit Dawit for their invaluable professional help initiatives and encouragement This research work also could have never been realized without the consistent support of the whole staff of Ambo Plant Protection Research Center (APPRC) and Alamata research center. I would like to thank Ethiopian Institute of Agricultura Research (EIAR) and Tigray Agricultural Research Institute (TARI) for the full financial support.

\section{References}

1. CSA (Central Statistical Agency) (1998) Report on Area and Crop Production Forecast for Major Grain Crops. Addis Ababa, Ethiopia.

2. CSA (2011) Report on area and crop production forecast for major crops (fo private peasant holdings, meher season). Statistical bulletin, Addis Ababa, Ethiopia.

3. Admassu B, Lind V, Friedt W, Ordon F (2009) Virulence analysis of Puccinia graminis f. sp. tritici populations in Ethiopia with special consideration of Ug 99. Plant Pathol 58: 362-369.

4. Leppik EE (1970) Gene centers of plants as sources of disease resistance. Ann Rev Phytopathol 8: 323-344.

5. Admassu B, Fekadu E (2005) Physiological races and virulence diversity of Puccinia graminis f. sp. tritici on wheat in Ethiopia. Phytopathol Mediterr 44: 313-318.

6. van Ginkel M, Getinet G, Tesfaye T (1989) Stripe, stem and leaf rust races in major wheat producing areas in Ethiopia. IAR Newslett Agric Res 3: 6-8.

7. Peterson RF, Campbell AB, Hannah A (1948) A diagrammatic scale for estimating rust intensity on leaves and stems of cereals. Canadaian Journal Research 26: 496-500

8. Stakman EC, Stewart DM, Loegering WQ (1962) Identification of physiologic races of Puccinia graminis var. tritici. USDA ARS, E716. United States Government Printing Office: Washington.

9. Fetch Jr TG, Dunsmore KM (2004) Physiological specialization of Puccinia graminis on wheat, barley, and oat in Canada in 2001. Can J Plant Pathol 26 148-155.

10. Roelfs AP, Martens JW (1988) An international system of nomenclature for $P$ graminis f. sp. tritici. Phytopathol 78: 526-533.

11. Jin Y, Szabo LJ, Pretorius ZA, Singh RP, Ward R, et al. (2008) Detection of virulence to resistance gene Sr24 within race TTKS of Puccinia graminis f. sp. tritici. Plant Dis 92: 923-926.

12. Ayele B, Eshetu B, Betelehem B, Bekele H, Melaku D, et al. (2008) Review of two decades of research on diseases of small cereal crops. Increasing crop production through improved plant protection volume I. Proceedings of $14^{\text {th }}$ ann Con. Addis Ababa, Ethiopia.

13. Dagnatchew $Y$ (1967) Plant disease of economic importance in Ethiopia. Hialeslassie I University, College of Agriculture, Environmental station bulletin, Addis Ababa, Ethiopia.

14. Roelfs AP, Singh RP, Saari EE (1992) Rust Diseases of Wheat: Concept and Methods of Disease Management. CIMMYT 81.

15. Mengistu H, Yeshi A (1992) Variation within indigenous durum wheat germplasm for response to stem and lesf races rust in Ethiopia. $7^{\text {th }}$ Regional wheat workshop for Eastern, Central and South Africa. Nakuru, Kenya CIMMYT Crop development department variety registration, Addis Ababa, Ethiopia.

16. Beteselassie N, Fininsa C, Badebo A (2007) Source of stem rust reistance in Ethiopian tetraploid wheat accessions. Afr Crop Sci J 15

17. CIMMYT (2005) Sounding the Alarm on Global Stem Rust. An assessment of race Ug99 in Kenya and Ethiopia and the potential for impact in neighboring regions and beyond. Prepared by the expert panel on the stem rust outbreak in Eastern Africa. CIMMYT, Mexico.

18. Pretorius ZA, Singh RP, Wagoire WW, Payne TS (2000) Detection of virulence to wheat stem rust resistance gene Sr31 in Puccinia graminis f. sp. tritici in Uganda. Plant Dis 84: 203.

19. Singh RP, Hodson DP, Huerta-Espino J, Jin Y, Njau P, et al. (2008) Will stem rust destroy the world's wheat crop? Advances in Agronomy 98: 271-309.

20. http://www.fao.org/agriculture/crops/rust/stem/rust-report/stem-report/en/ 